\title{
Single-cell analysis of bacterial growth, cell size, and community structure in the Delaware estuary
}

\author{
Matthew T. Cottrell ${ }^{*}$, David L. Kirchman \\ College of Marine Studies, University of Delaware, 700 Pilottown Road, Lewes, Delaware 19958, USA
}

\begin{abstract}
The abundance and size of thymidine and leucine-assimilating bacteria were examined using a combination of microautoradiography and fluorescence in situ hybridization (micro-FISH) to explore the relationship between community structure and bacterial growth in the Delaware estuary. Community structure varied along the salinity gradient; $\beta$-proteobacteria and Cytophaga-like bacteria dominated in freshwater parts of the estuary and $\alpha$-proteobacteria were the most abundant bacteria at salinities greater than about 10 PSU. The percentage of thymidine and leucine-assimilating bacteria in these groups varied substantially as well, ranging from undetectable to $50 \%$ active. The correlation between abundance and the fraction of bacteria assimilating ${ }^{3} \mathrm{H}$-thymidine was significant for $\beta$-proteobacteria, suggesting that the decline in the abundance of these bacteria in high salinity waters was because of slower growth. The correlation between abundance and growth, however, was not significant for the other types of bacteria we examined. Active bacteria were distributed across all size classes, and the smallest bacteria dominated cell number and cell volume. This study indicates that bacterial growth has a smaller impact on community structure than expected, and points towards the importance of other factors, such as mortality, in affecting community structure.
\end{abstract}

KEY WORDS: Proteobacteria $\cdot$ Cytophaga $\cdot$ Microautoradiography $\cdot$ Thymidine $\cdot$ Leucine

Resale or republication not permitted without written consent of the publisher

\section{INTRODUCTION}

The composition of bacterial communities has the potential to influence food webs and the cycling of elements in aquatic systems. Carbon cycling may be impacted by the interaction of different kinds of bacteria with dissolved organic matter (DOM), since hydrolysis of polymeric compounds is not uniformly distributed among cultured bacteria (Martinez et al. 1996) and various types of uncultured bacteria in aquatic systems, including Proteobacteria and Cytophaga-like bacteria, appear to differ in the uptake of DOM compounds (Cottrell \& Kirchman 2000). The cycling of nitrogen is impacted by bacterial diversity (Ward 1996, 2000, Paerl \& Zehr 2000) and bacteria differ in metabolizing various sulfur containing compounds, which has implications for sulfur cycling (Gonzalez et al. 1999, Zubkov et al. 2001, Malmstrom et al. in press). The structure of bacterial communities is probably important in the processing of trace metals as well
(Granger \& Price 1999, Tortell et al. 1999, Hutchins et al. 2001).

Bacterial community structure may be influenced by the factors controlling bacterial growth. Heterotrophic bacteria are typically carbon-limited in marine environments (Ducklow 2000, Kirchman et al. 2000), although inorganic nutrients, such as phosphorous, can be limiting as well (Cotner et al. 1997). Since the consumption of various DOM components differs among bacteria (Cottrell \& Kirchman 2000, Eilers et al. 2000a), the availability of substrates may influence the growth of different bacterial groups (Cottrell \& Kirchman 2003). In addition to nutrient limitation, factors inhibiting or inactivating bacteria (Bouvier \& del Giorgio 2002, del Giorgio \& Bouvier 2002) may also contribute to differences in growth rates. Regardless of the limiting factors, growth rates appear to vary greatly within and between the major phylogenetic groups of bacteria found in aquatic systems (Kirchman 2002, Cottrell \& Kirchman 2003). Therefore, community 
structure may reflect differences in growth rates if faster growing bacteria achieve higher abundances than slower growing bacteria.

The structure of bacterial communities may also be influenced by mortality, including grazing by bacterivores (Strom 2000) and viral lysis (Fuhrman \& Suttle 1993, Wommack \& Colwell 2000). Grazing pressure can alter community structure when some members of the community are resistant to grazing (Šimek et al. 1997, Pernthaler et al. 2001). In addition to impacting community composition, grazing can alter the size distribution of bacterial biomass and potentially remove the most active bacteria (Sherr et al. 1992, Pernthaler et al. 1996). Viral lysis can also be size specific and remove the largest cells (Murray \& Jackson 1992, Weinbauer \& Höfle 1998b). Variation in bacterial cell size can in turn influence the trophic transfer of materials and energy because grazing efficiency varies with cell size (Gonzalez et al. 1990, Jürgens \& Güde 1994, Jürgens et al. 1994).

The goal of this study was to examine how the relative abundance of the major bacterial groups in the Delaware estuary is related to growth $\left({ }^{3} \mathrm{H}\right.$-thymidine and ${ }^{3} \mathrm{H}$-leucine assimilation) and size structure. Estuaries like the Delaware are good environments to examine the factors influencing bacterial community structure, because the environmental gradients are steep and community composition changes substantially in the transition between freshwater and coastal environments (Crump et al. 1999, Bouvier \& del Giorgio 2002). Four locations in the bay were sampled in March and June 2001 to test the hypothesis that changes in the percentage of different bacteria assimilating ${ }^{3} \mathrm{H}$-thymidine and ${ }^{3} \mathrm{H}$-leucine, i.e. bacteria growth and production, determine the abundance of the major bacterial groups. We expected that the more abundant bacterial groups would have larger cells and higher fractions of active bacteria assimilating ${ }^{3} \mathrm{H}$-thymidine and ${ }^{3} \mathrm{H}$ leucine. Contrary to our expectation, data on growth and cell size suggest that growth may be less important than other factors, such as mortality, in determining bacterial community structure in estuaries.

\section{MATERIALS AND METHODS}

Sample collection and incubation. Cottrell \& Kirchman (2003) reported on the contribution of different bacteria to bacterial production in the Delaware estuary as estimated by the fraction of thymidine and leucine incorporation accounted for by the major bacterial groups. In this study, we examined growth within bacterial groups as the fraction of cells within the major bacterial groups assimilating thymidine and leucine. Seawater was collected in Delaware Bay from a depth of $1 \mathrm{~m}$ in March and June 2001. Samples for microautoradiography were incubated with $20 \mathrm{nM}^{3} \mathrm{H}$ thymidine and ${ }^{3} \mathrm{H}$-leucine at in situ temperature for $4 \mathrm{~h}$. Killed controls were poisoned with $2 \%$ paraformaldehyde. Incubations were terminated by adding $20 \%$ paraformaldehyde to a final concentration of $2 \%$. Samples were fixed at $4{ }^{\circ} \mathrm{C}$ overnight and then $20 \mathrm{ml}$ were collected on $0.2 \mu \mathrm{m}$ pore-size polycarbonate filters supported with $0.45 \mu \mathrm{m}$ nitrocellulose membranes, rinsed twice with deionized water and stored at $-20^{\circ} \mathrm{C}$.

Microautoradiography and fluorescence in situ hybridization (micro-FISH). Samples for in situ hybridization were prepared using a modified micro-FISH procedure (Cottrell \& Kirchman 2000). Polycarbonate filters were cut into 12 pieces and placed with the celladherent side in contact with a $30 \mu \mathrm{l}$ drop of hybridization solution containing $2 \mathrm{ng}$ of probe per $\mu \mathrm{l}$ on a glass slide covered with parafilm. The relative abundance of major phylogenetic groups was determined using CY3labeled (Operon Technologies) probe Eub338 for eubacteria (Amann et al. 1990), Alf968 for $\alpha$-proteobacteria (Glöckner et al. 1999), Bet42a for $\beta$-proteobacteria (Manz et al. 1992), Gam42a for $\gamma$-proteobacteria, CF319a for the Cytophaga-like bacterial group (Manz et al. 1996), and a negative control probe for non-specific binding (Karner \& Fuhrman 1997). Samples were incubated for 18 to $20 \mathrm{~h}$ at $42^{\circ} \mathrm{C}$. The hybridization solution contained $0.9 \mathrm{M} \mathrm{NaCl}, 20 \mathrm{mM}$ Tris- $\mathrm{HCl}(\mathrm{pH}$ $7.4), 0.1 \%$ sodium dodecyl sulfate, and the concentration of formamide determined to achieve specificity for the bacterial groups targeted by the different probes (Zarda et al. 1997, Eilers et al. 2000b). After hybridization, the samples were transferred to a wash solution containing $20 \mathrm{mM}$ Tris-HCL (pH 7.4), 5 mM EDTA, $0.01 \%$ sodium dodecyl sulfate, and a concentration of $\mathrm{NaCl}$ appropriate for the probe (Zarda et al. 1997, Eilers et al. 2000b). The sample was then rinsed with water and air-dried.

After the FISH procedure, polycarbonate filters were prepared for autoradiography using the approach introduced by Tabor \& Neihof (1984; Carman 1993). A series of exposure times, typically 1, 3, 8, 24 and $48 \mathrm{~h}$, was tested to determine 2 exposure times that would yield approximately 10 and $30 \%$ of the total community with silver grains. These exposure times were then used in autoradiography. Short thymidine and leucine exposure times ranged from 8 to $24 \mathrm{~h}$ and 1 to $3 \mathrm{~h}$, respectively. Long thymidine and leucine exposure times ranged from 28 to $48 \mathrm{~h}$ and 3 to $7 \mathrm{~h}$, respectively.

Polycarbonate filters were prepared for microautoradiography by dipping a glass slide into a molten $\left(43^{\circ} \mathrm{C}\right)$ solution of NTB-2 emulsion (Kodak) diluted to 2 parts emulsion and 1 part deionized water. The filters were placed with the cell adherent side in contact with the molten emulsion. The glass slide was then placed on an 
ice-cold aluminum block for 10 min to solidify the emulsion before being transferred to light tight boxes for autoradiographic exposure times that ranged from 1 to $48 \mathrm{~h}$. The exposures for $8 \mathrm{~h}$ or less were done at room temperature while longer exposures were done at $4^{\circ} \mathrm{C}$. Emulsion was developed using Dektol developer (Kodak), a deionized-water stop bath and fixer (Kodak) following the manufacturer's instructions. The slides were then rinsed in water for $10 \mathrm{~min}$, dried overnight in a vacuum chamber with desiccant and then stained in a $2 \mu \mathrm{g}$ $\mathrm{ml}^{-1}$ solution of DAPI for $2 \mathrm{~min}$. After a final rinse in deionized water, $80 \%$ ethanol and $1 \%$ glycerol, the emulsion was once again dried overnight in a vacuum desiccator and the polycarbonate filter was peeled away from the emulsion. The sample was mounted with a cover slip using a 4:1 mixture of the antifade mountants Citifluor (Ted Pella) and Vectashield (Vector Labs).

Semi-automated microscopy and image analysis. Samples were assayed using semi-automated microscopy and image analysis of fluorescence and transmitted light images acquired with a charge coupled device (CCD) camera mounted on an Olympus Provis AX70 microscope (Cottrell \& Kirchman 2003). Bacterial cell volumes were measured from solids of revolution constructed by digital integration (Sieracki et al. 1989). Cell sizes and relative abundances (FISH) were transformed using the logarithmic and the arcsine transformation, respectively, to satisfy the assumptions of the statistical analyses used here.

\section{RESULTS}

\section{Bacterial community composition}

Community structure varied along the salinity gradient in the Delaware Bay similarly in March (Cottrell \& Kirchman 2003) and June 2001. The abundance of $\alpha$-proteobacteria was lowest in freshwater and increased with salinity, while $\beta$-proteobacteria exhibited the opposite trend; their abundance was highest in freshwater and decreased with increasing salinity (Fig. 1A,B). At salinities less than 16 PSU, $\alpha$-proteobacteria accounted for less than $15 \%$ of the community, whereas at 16 PSU and higher, $\alpha$-proteobacteria comprised 20 and $40 \%$ of the community. Cytophaga-like bacteria were an important component of the bacterioplankton with abundances typically ranging from 5 to $20 \%$ of the community; the notable exception was the freshwater station in March when Cytophaga-like bacteria comprised $40 \%$ of the community. Gamma-proteobacteria were detected at every salinity, but these bacteria never made up a substantial portion of the community with abundances typically less than $12 \%$ of the prokaryotes.

\section{Bacteria assimilating ${ }^{3} \mathrm{H}$-thymidine and ${ }^{3} \mathrm{H}$-leucine}

The fraction of bacteria assimilating thymidine and leucine varied substantially in the bacterial groups we examined. The percentage of $\beta$ - and $\gamma$-proteobacteria, and Cytophaga-like bacteria assimilating these 2 tritiated tracers of bacterial production varied from 0 to $51 \%$ (Table 1). There was no consistent pattern along the salinity gradient or between seasons. For example, in March thymidine assimilation by Cytophaga-like bacteria varied inversely with salinity, while the pattern was reversed in June (Table 1).

There was also no clear relationship between the fraction of thymidine-active and leucine-active bacteria $(\mathrm{r}=0.43)$, and the variation in leucine-active bacteria along the estuarine gradient differed from that of thymidine-active bacteria. For example, thymidine-active Cytophaga-like bacteria and $\beta$-proteobacteria varied substantially with salinity, while leucineactive bacteria in these 2 groups were the same at

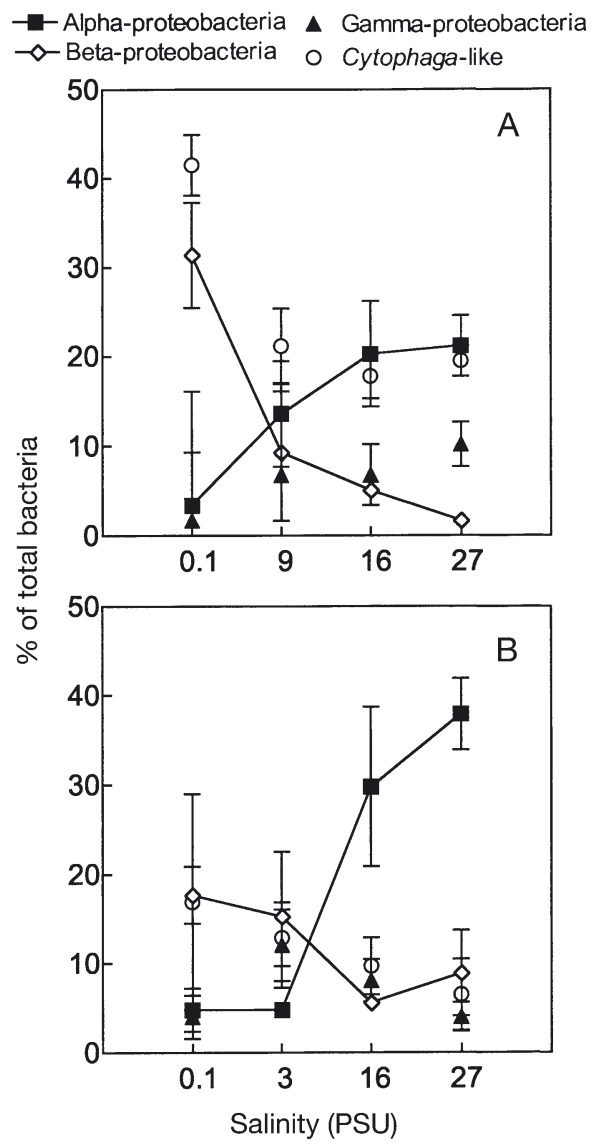

Fig. 1. Relative abundance of bacterial groups at 4 locations in the Delaware Bay in (A) March and (B) June 2001. The March data were taken from Cottrell \& Kirchman (2003). Values are means $\pm \mathrm{SE}$ 
Table 1. Percentage $( \pm \mathrm{SE})$ of $\alpha-, \beta-, \gamma$-proteobacteria and Cytophaga-like bacteria assimilating ${ }^{3} \mathrm{H}$-thymidine and ${ }^{3} \mathrm{H}$-leucine in the Delaware estuary in 2001. ND: not determined

\begin{tabular}{|c|c|c|c|c|c|c|c|c|c|}
\hline \multirow[t]{3}{*}{ Month } & \multirow[t]{3}{*}{ Salitnity (PSU) } & \multirow{2}{*}{\multicolumn{4}{|c|}{$\begin{array}{l}\text { Proteobacteria }\end{array}$}} & \multirow{2}{*}{\multicolumn{4}{|c|}{$\%$ assimilating ${ }^{3} \mathrm{H}$-leucine }} \\
\hline & & & & & & & & & \\
\hline & & $\alpha$ & $\beta$ & $\gamma$ & Cytophaga-like & $\alpha$ & $\beta$ & $\gamma$ & Cytophaga-like \\
\hline \multirow[t]{4}{*}{ March } & 0.1 & $31(12)$ & $51(6)$ & $27(7)$ & $27(3)$ & $0(0)$ & $33(56)$ & $50(0)$ & $10(2)$ \\
\hline & 9 & $39(6)$ & $28(9)$ & $26(9)$ & $11(4)$ & $49(7)$ & 43 (13) & $18(10)$ & $17(3)$ \\
\hline & 16 & $14(5)$ & $0(0)$ & $3(3)$ & $5(2)$ & $27(11)$ & $6(3)$ & $0(0)$ & $4(2)$ \\
\hline & 29 & $22(5)$ & $0(0)$ & $5(2)$ & $5(2)$ & $40(3)$ & 41 (15) & $36(9)$ & $14(4)$ \\
\hline \multirow[t]{4}{*}{ June } & 0.1 & $13(12)$ & $14(2)$ & $12(4)$ & $4(1)$ & $24(1)$ & $23(9)$ & $17(3)$ & $28(3)$ \\
\hline & 3 & $26(4)$ & $32(3)$ & $29(5)$ & $23(2)$ & $20(6)$ & $0(0)$ & $14(3)$ & $7(3)$ \\
\hline & 16 & $20(2)$ & $23(5)$ & $7(1)$ & $13(2)$ & $34(3)$ & $32(7)$ & $32(5)$ & $11(3)$ \\
\hline & 27 & $34(4)$ & $23(5)$ & $27(4)$ & $30(8)$ & ND & ND & ND & ND \\
\hline
\end{tabular}

the freshwater and 29 PSU stations in March (Table 1). In June, thymidine-active $\alpha$-proteobacteria ranged from undetectable to $50 \%$ of total $\alpha$-proteobacteria abundance, while the percentage that were leucine-active was much less variable, varying from 20 to $35 \%$.

\section{Correlation between bacterial abundance and activity}

We examined the relationship between bacterial abundance and activity to test the hypothesis that community structure is determined by factors controlling growth. There was no significant correlation between the percentage of $\alpha-, \beta$, and $\gamma$-proteobacteria and Cytophaga-like bacteria that were thymidine- or leucine-active and their relative abundance in March and June. Correlation coefficients calculated for thymidine and leucine in March and June varied from -0.76 to 0.95 , but none were significant. Pooling the seasonal data, which doubled the sample size from 4 to 8 , revealed a significant relationship $(\mathrm{r}=0.80 ; \mathrm{p}<0.05)$ for thymidine-active $\beta$-proteobacteria (Fig. 2). Correlation coefficients for the other groups varied from -0.20 for $\gamma$ proteobacteria to 0.08 for the Cytophaga-like bacteria. Correlations between abundance and active bacteria in the pooled ${ }^{3} \mathrm{H}$-leucine data ranged from 0.04 to 0.39 , but none were significant. These analyses support the conclusion that the abundance of $\beta$-proteobacteria may be controlled by growth.

\section{Active and inactive bacteria detected by FISH}

We examined the percentage of thymidine and leucine-active bacteria detected by FISH to determine whether a larger fraction of active bacteria is detected by FISH than inactive bacteria. The percentage of bacteria detected by FISH with the general bacterial probe

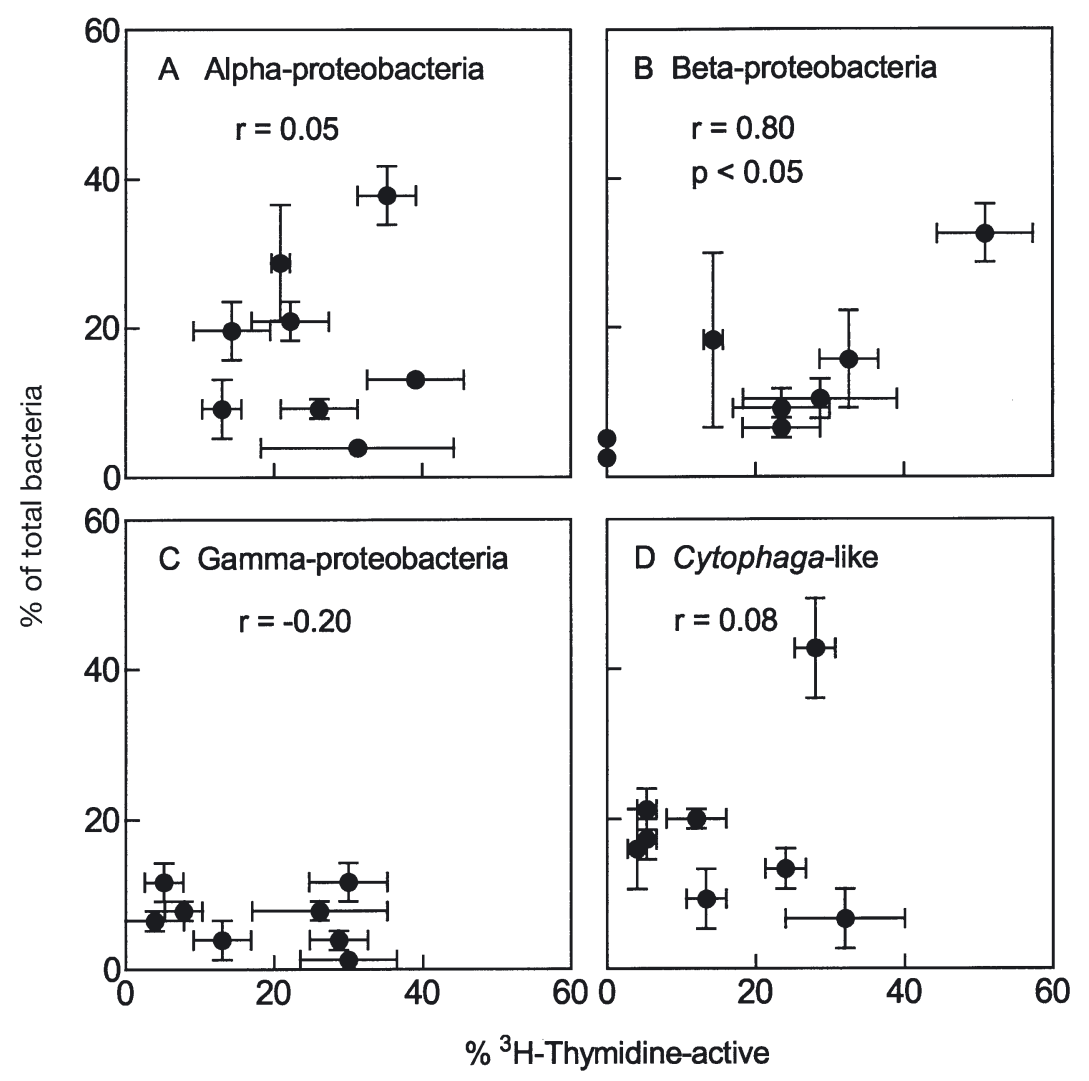

Fig. 2. Correlation between the relative abundance of (A) $\alpha$, (B) $\beta$-proteobacteria, (C), $\gamma$-proteobacteria, and (D) Cytophaga-like bacteria, and the percentage of ${ }^{3} \mathrm{H}$-thymidine active bacteria in these groups in Delaware Bay in March and June 2001. The relationship for $\beta$-proteobacteria showed the only significant correlation. Values are means $\pm \mathrm{SE}$ 


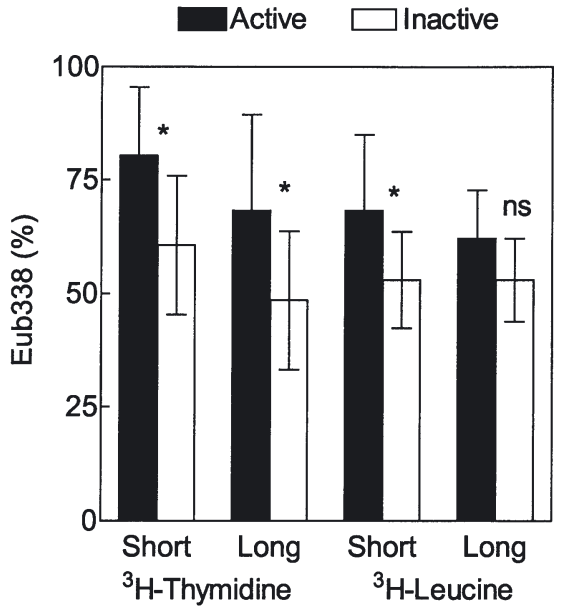

Fig. 3. Percentage of bacteria detected with the General Bacterial Probe Eub338. Filled bars indicate bacteria actively assimilating ${ }^{3} \mathrm{H}$-thymidine or ${ }^{3} \mathrm{H}$-leucine; open bars indicate no detectable assimilation. Error bars indicate the SE of the mean percentage for 4 stations in the Delaware Bay sampled in March and June 2001. Significant differences $(p<0.05)$ between thymidine- and leucine-active and -inactive bacteria (paired $t$-test) are indicated by ${ }^{*}$; ns: no significant difference

(Eub338) was significantly higher for bacteria actively assimilating ${ }^{3} \mathrm{H}$-thymidine and ${ }^{3} \mathrm{H}$-leucine than inactive bacteria (paired $t$-test, $\mathrm{p}<0.05$ ) (Fig. 3). Of thymidineassimilating bacteria, $80 \pm 15 \%$ (SE) were detected by FISH compared to $60 \pm 15 \%$ for thymidine-inactive bacteria. The difference between leucine-active and inactive bacteria was similar, with $68 \pm 17$ and $52 \pm 11 \%$ of active and inactive bacteria, respectively, detected with the general bacterial probe. The percentages of thymidine and leucine-active bacteria detected by FISH were $1.36 \pm 0.29$-fold and $1.32 \pm 0.27$-fold higher than inactive bacteria in March and June. The results were similar with a longer autoradiographic exposure time, which yielded $27 \%$ apparently active bacteria versus $14 \%$ for the short exposure time. With the longer exposure, the percentages of ${ }^{3} \mathrm{H}$-thymidine and ${ }^{3} \mathrm{H}$ leucine active bacteria detected by FISH were $1.47 \pm$ 0.36 -fold and $1.23 \pm 0.29$-fold higher, respectively, compared to inactive bacteria.

Although more thymidine and leucine-active bacteria were detected by FISH than inactive bacteria, bacterial activity explained less than $35 \%$ of the variation in the percentage of bacteria detected by FISH with the Eub338 probe. The percentage of thymidine and leucine-active bacteria varied from 10 to $42 \%$ and 20 to $42 \%$, respectively, while the percentage of cells that were visible with the general bacterial probe varied from 35 to $70 \%$. The correlation coefficient (r) of percent probe-positive bacteria versus percent active bacteria was not significant for ${ }^{3} \mathrm{H}$-thymidine and ${ }^{3} \mathrm{H}$ leucine $(p>0.05)$.

\section{Size of probe-positive and ${ }^{3} \mathrm{H}$-thymidine and ${ }^{3} \mathrm{H}$-leucine active bacteria}

Bacterial sizes varied considerably in the Delaware, with differences at the whole community level and between bacteria detected and not detected with FISH probes. Average bacterial cell volumes of Eub338-positive and -negative bacteria ranged from $0.018 \mu^{3}$ at the 16 PSU station in June to $0.040 \mu^{3}$ at the 29 PSU station in March (Fig. 4). The difference in size between Eub338-positive and -negative bacteria was significant at all 4 sampling locations in March and June (ANOVA, p < 0.05). Eub338-positive bacteria were 1.3- to 1.4-fold larger than Eub338-negative bacteria in March at 0.1 PSU and 27 PSU (Fig. 4A). The probe-positive bacteria were 1.2- to 1.4-fold larger in June at these salinities (Fig. 4B). In contrast, in June at intermediate salinities between 3 and 16 PSU, Eub338positive bacteria were 0.7 - to 0.9 -fold smaller than probe-negative bacteria (Fig. 4B).

There was a significant negative correlation between bacterial size and relative abundance $(\mathrm{r}=-0.40$; $\mathrm{p}<$ 0.05 ). If we restrict our analysis to bacteria comprising

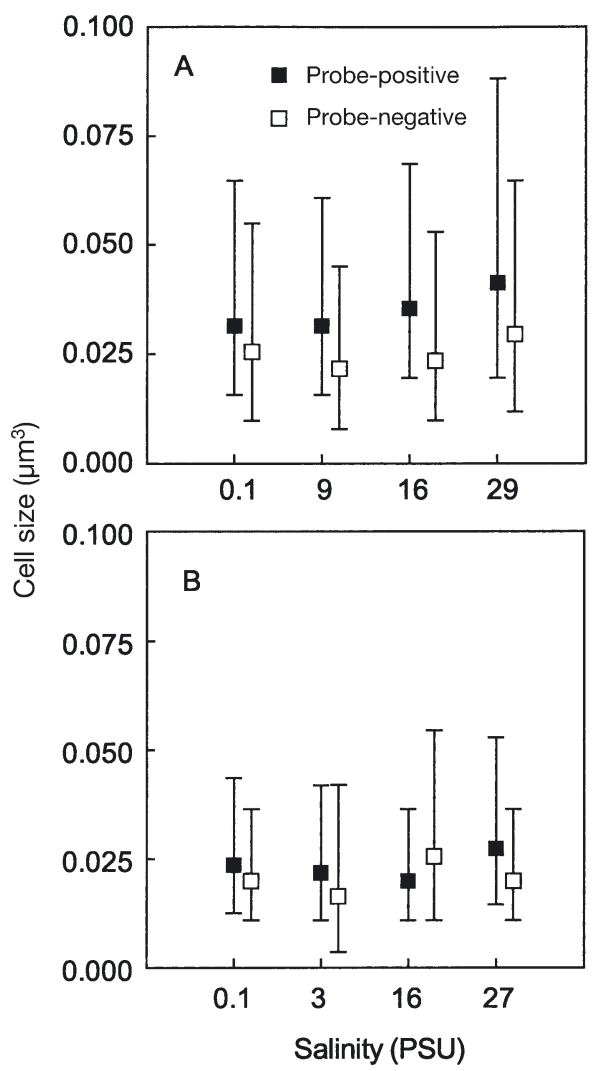

Fig. 4. Cell volumes of probe-positive and probe-negative bacteria at 4 Delaware Bay stations in (A) March and (B) June 2001. Error bars indicate SE of the mean of 4 FISH assays using the general bacterial probe Eub338 


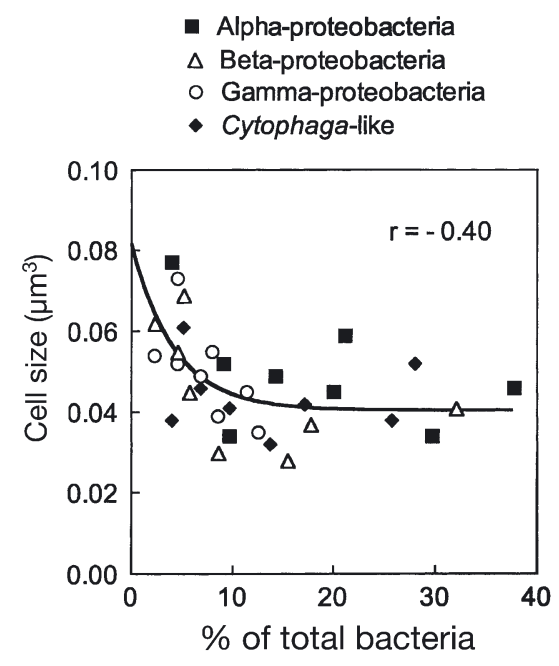

Fig. 5. Correlation between the relative abundance of $\alpha-, \beta$ and $\gamma$-proteobacteria and Cytophaga-like bacteria and cell size at 4 locations in the Delaware estuary in March and June 2001. The linear correlation was significant $(p<0.05)$. The curve was fit using an exponential model

less than $15 \%$ of the total community, the correlation is somewhat higher $(\mathrm{r}=-0.60$; $\mathrm{p}<0.05)$. There was no significant correlation between bacterial size and relative abundance for bacteria comprising more than $15 \%$ of the total community (Fig. 5). Less abundant bacterial groups were as much as 2-fold larger than cells in the more abundant bacterial groups (Fig. 5). There was no significant correlation between the abundance and cell size when $\alpha-, \beta-$, and $\gamma$ proteobacteria and Cytophaga-like bacteria were examined separately because of small sample sizes. Nevertheless, all bacterial groups appear to follow the pattern set by the pooled data (Fig. 5).

Thymidine- and leucine-active proteobacteria and Cytophaga-like bacteria were 0.3 times smaller to 1.5 times larger than the inactive bacteria in these phylogenetic groups (Fig. 6). Even though the difference in size seems substantial in some instances, statistical significance could not be demonstrated due to the large variation in cell size and the relatively small number of bacteria examined. In June, for example, active $\gamma$-proteobacteria $\left(0.089 \pm 0.035 \mu^{3}\right)$ were almost twice the size of inactive bacteria in this group $\left(0.048 \pm 0.012 \mu \mathrm{m}^{3}\right)$, but this difference is not statistically significant. Both thymidine and leucine-active and inactive bacteria varied substantially in size (coefficient of variation equal to $80 \%$ ) (Fig. 6).

The distribution of bacterial cell sizes was highly skewed with the largest numbers of bacteria in the smallest size class (0.01 to $0.04 \mu^{3}$ ) (Fig. 7). Bacteria in the 0.05 to $0.1 \mu^{3}$ size classes made up the remaining portion of the community with only a few bacteria represented in the largest size classes $\left(>0.1 \mu \mathrm{m}^{3}\right)$. The percentage of thymidine and leucine-active bacteria varied with cell size (Fig. 7). Percent thymidine-active bacteria varied from 6 to $47 \%$ in the 0.01 to $0.1 \mu^{3}$ size classes where bacteria were most numerous. There was no significant correlation between the percentage of thymidine and leucine-active bacteria and size across all size classes $(r=0.092 ; p>0.05)$.

\section{DISCUSSION}

One goal of this study was to determine whether differences in growth among bacterial groups explains the switch from dominance by $\beta$-proteobacteria in freshwater to $\alpha$-proteobacteria at higher salinities. We anticipated that factors which co-vary with salinity,

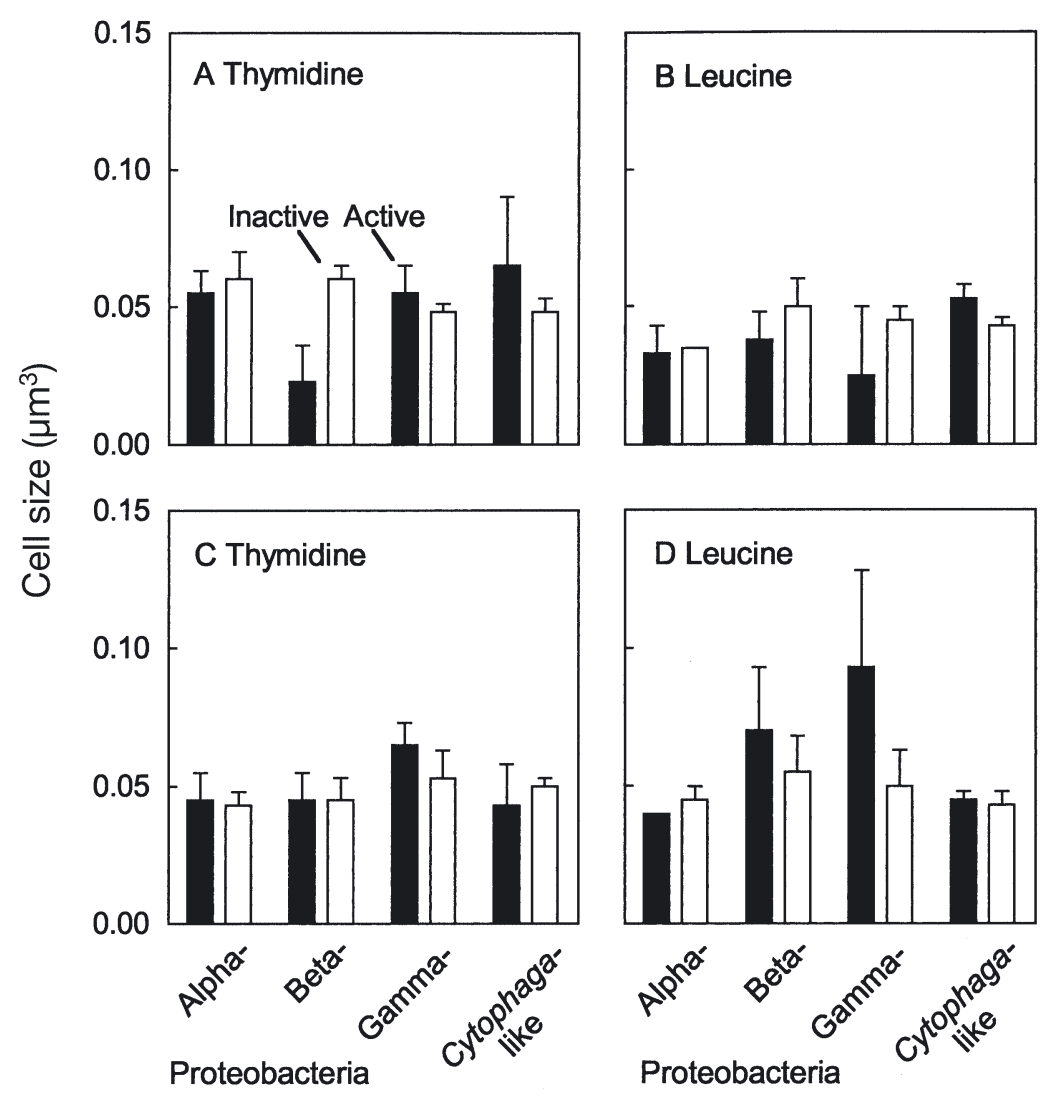

Fig. 6. Cell volumes of ${ }^{3} \mathrm{H}$-thymidine and ${ }^{3} \mathrm{H}$-leucine active (filled bars) and inactive (open bars) bacteria in (A, B) March, and (C, D) June in Delaware Bay 


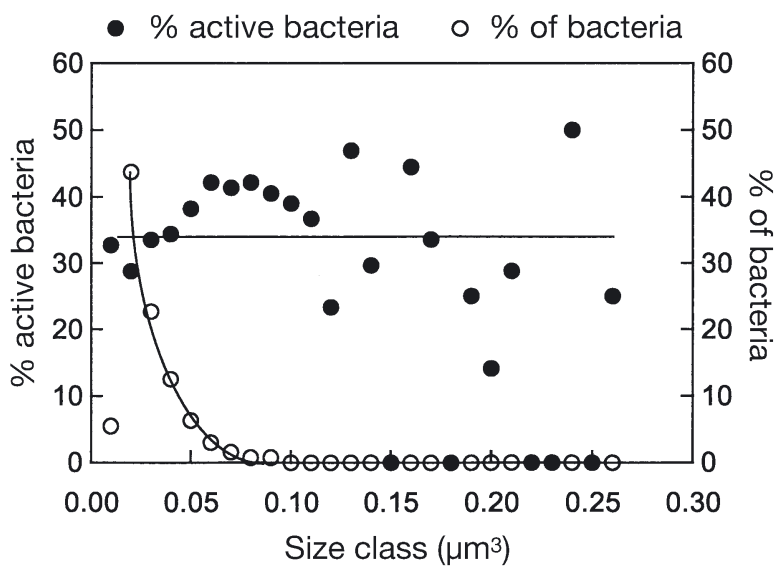

Fig. 7. Distribution of percentage thymidine-active and total bacteria as a function of cell size. Bacteria were sampled at 4 stations along the salinity gradient from 0.1 to 29 PSU in March 2001. Open and filled circles indicate percentages of bacteria and percent active, respectively, in $0.01 \mathrm{\mu m}^{3}$ sizeclass bins. $x$-axis indicates top of bin

and potentially influence growth, would determine community structure. These factors could include competition for substrates that limit growth, such as organic carbon (Kirchman et al. 2000) or inorganic nutrients (Cotner et al. 1997), and inhibition of bacterial growth by factors such as salinity (del Giorgio \& Bouvier 2002). We found that the abundance of only $\beta$ proteobacteria could be explained by growth. We expected that abundant bacterial groups would have higher proportions of actively growing cells and that populations of slower growing bacterial groups with fewer thymidine- and leucine-active cells would be less abundant. Instead, the relative abundance of bacterial groups and the percentage that were thymidineand leucine-active varied independently, except for $\beta$ proteobacteria. These data suggest that growth rate does not determine the abundance of the major bacterial groups, except perhaps for $\beta$-proteobacteria.

Our analysis is of the contemporaneous association between active bacteria and bacterial abundance. However, time-lags between increases in macromolecular synthesis and abundance could mask the association between the fraction of thymidine- or leucineactive bacteria and bacterial abundance. In the Delaware estuary and probably elsewhere, rates of DNA and protein synthesis by bacterial assemblages can be uncoupled when protein synthesis changes more rapidly than DNA synthesis due to a shift up or down in growth conditions (Chin-Leo \& Kirchman 1990). However, this uncoupling problem is not likely to explain the lack of a correlation between abundance and macromolecular synthesis. The duration of the uncoupling between protein and DNA synthesis is always shorter than the generation time, which is on the order of a day in the Delaware (Hoch \& Kirchman 1993). The relatively short duration of the metabolic shift-up reduces the chances of sampling bacteria in this transient state of growth. In fact, it would probably be necessary to sample several times a day in order to observe this type of uncoupling.

We also considered the possibility that advection could play a role in disrupting the correlation between bacterial growth and abundance. As bacteria are transported down the bay, an uncoupling between macromolecular synthesis and cell division could result in a spatial offset between activity and abundance of the phylogenetic groups we examined. However, there was no clear relationship between the percentage of active $\alpha$-proteobacteria at low salinity located upstream and their abundance further down stream. There was one case in which elevated activity occurred upstream of high abundance; in June, the percentage of thymidine-active $\alpha$-proteobacteria was elevated upstream of the station further down the salinity gradient where their abundance was highest. But in all other cases high abundances of bacterial groups were not located downstream of high percentages of active bacteria in that group.

Another important consideration is whether or not the analysis of thymidine- and leucine-active and -inactive bacteria is sensitive to potential biases in the detection of bacteria by FISH (Bouvier \& del Giorgio 2003). FISH hybridization can vary with the stage of growth in cultured bacteria; fewer bacteria are detected when growth of the cultures ceases (Ruimy et al. 1994). In California coastal waters, the abundance of bacteria detected by FISH with a universal probe was highly correlated with the abundance of amino acid autoradiography-positive bacteria $(r=0.97)$, suggesting that FISH detects the metabolically active bacteria (Karner \& Fuhrman 1997). However, when variation in the total bacterial abundance is controlled by analyzing the percentage of active and probe-positive bacteria, the correlation is lower $(\mathrm{r}=0.61)$, and not statistically significant, indicating that bacterial activity and detection by FISH are only weakly associated. In the Delaware, we also found a low correlation between the percentage of bacteria detected by FISH and active bacteria. Our image analysis data indicate that the fraction of thymidine and leucine-active and -inactive bacteria detected by FISH typically differed by only $25 \%$. The correlation between FISH detection and bacterial activity is often low in individual studies, but higher in data pooled from different studies (Bouvier \& del Giorgio 2003).

The fraction of a bacterial group that is active would be overestimated if FISH identified a smaller fraction of inactive bacteria than active bacteria. The active 
fraction would be overestimated if the total number of bacteria belonging to a group were underestimated because the inactive bacteria were missed by FISH. However, the maximum overestimation of active bacteria would be $33 \%$ when inactive bacteria approach $100 \%$ of the total. When inactive bacteria are half of the total the overestimation would be $14 \%$. Even with this degree of overestimation, our sampling should have been able to detect a significant correlation between active bacteria and bacterial abundance. In fact, we did not see this correlation, except for $\beta$ proteobacteria, suggesting that growth factors do not determine community composition.

The processes that are responsible for determining community composition appear to be similar for all estuaries, since the structure of bacterial communities is similar for the estuaries examined to date. The dominance of $\beta$-proteobacteria in freshwater and $\alpha$ proteobacteria in saltwater is a common feature of several estuaries. In the Choptank and the Pocomoke Rivers, which are subestuaries of the Chesapeake Bay, $\beta$-proteobacteria dominate freshwater portions of the estuary while $\alpha$-proteobacteria dominate saltwater regions (Bouvier \& del Giorgio 2002). There is a similar pattern in the Columbia River estuary for free-living and particle-associated bacterial communities; the greatest changes in $\alpha$ - and $\beta$-proteobacteria occur in the free-living and attached communities, respectively (Crump et al. 1999).

Although there are many similarities, the structure of bacterial communities in the estuaries listed above can differ, which may be due at least indirectly to differences in watersheds, geography and other factors, including aspects of food web structure, such as the abundance, diversity and selectivity of grazers (Gonzalez et al. 1990, Pernthaler et al. 1996, Beardsley et al. 2003). The high abundance of Cytophaga-like bacteria in low salinity waters distinguishes the Delaware from the Choptank, Pocomoke and the Columbia River estuary where Cytophaga-like bacteria are most abundant at an intermediate salinity in the turbidity maximum region (Crump et al. 1999, Bouvier \& del Giorgio 2002). Likewise, estuaries on the US east and west coast have different watersheds and sources of allochthonous organic matter inputs (Hopkinson et al. 1998, Harvey \& Mannino 2001). While the Chesapeake and Delaware estuaries may have more in common due to their proximity (Kim et al. 2000), they differ greatly in anthropogenic inputs and the nature of the high salinity end member (Fisher et al. 1998). The Delaware communicates directly with the Atlantic, whereas the Pocomoke and Choptank empty into the Chesapeake. It is unclear how these large-scale differences in estuaries cascade down to the level of processes directly governing the composition of bacterial communities.
The obvious factor that all estuaries have in common is a salinity gradient. However, although community structure varies with salinity, it seems unlikely that salinity alone is the determining factor. For example, we always detected $\beta$-proteobacteria at the highest salinity and usually 30 to $50 \%$ of this bacterial group assimilated thymidine and leucine, which was similar to the fraction of active $\alpha$-proteobacteria in high salinity waters. Similarly, the thymidine and leucine-active $\alpha$-proteobacteria were always detected at the freshwater stations. Clearly some $\beta$-proteobacteria are capable of growing at elevated salinity, and likewise for $\alpha$-proteobacteria in the freshwaters of the Delaware River.

Another growth-related hypothesis is that community structure varies because of growth history and senescence. Bacterial cultures typically grow exponentially before entering a period senescence, which is characterized by high bacterial abundance, low cellular activity and small cell-size (Morita 1997). We examined the relationship among bacterial abundance, activity and cell size in order to test whether bacteria in the Delaware estuary fit this model, which predicts that the most abundant bacteria would be small and senescent. In our study the relationship between cell size and activity did not fit the model completely. In the Delaware, the most abundant bacteria were in fact the smallest. However, the small bacteria that dominate in the Delaware have a wide range of activities, and most are not senescent, based on our data on thymidine and leucine assimilation.

Factors influencing growth such as DOM and salinity do not appear to fully explain the switch between dominance by $\alpha$-proteobacteria and $\beta$-proteobacteria along estuarine salinity gradients. Removal processes, such as grazing, need to be considered. Grazers can select for different types of bacteria (Pernthaler et al. 2001) and therefore could influence community structure. One study of North Sea bacterioplankton suggested that low abundances of the $\gamma$-proteobacterial genera Alteromonas, Pseudoalteromonas, and Vibrio are maintained by selective grazing (Beardsley et al. 2003). Modeling studies (Hahn \& Höfle 2001) and chemostat experiments (Hahn \& Höfle 1999) suggest that the impact of mortality on bacterial community structure may also be found in the size distribution of bacteria. In our study, bacterial cell sizes were highly skewed and there was a significant negative correlation between bacterial cell size and relative abundance, which is consistent with size-selective mortality by grazers (Strom 2000) or viruses (Weinbauer \& Höfle 1998b). Closer inspection of the correlation between bacterial cell size and abundance revealed that the association between size and abundance was attributable to bacterial groups comprising less than $15 \%$ of the total community, while there was no significant 
correlation for bacteria comprising more than $15 \%$ of the community. The lack of a significant correlation for the more abundant bacterial groups suggests that the grazing pressure on bacteria comprising more than $15 \%$ of the community is sufficient to maintain a uniformly small cell-size. It appears that bacteria with abundances below this threshold experience reduced grazing pressure, allowing them to grow larger.

The relationships among bacterial growth, community structure and the size distribution of bacteria probably vary with the environment. For example, the impact of grazing is likely to differ in lakes where grazing-resistant bacteria tend to be larger and filamentous (Pernthaler et al. 1996). In the Delaware, cell sizes were the same in the freshwater and saline parts of the estuary (Kirchman et al. 2003), and filamentous bacteria were never abundant. Viral and grazing mortality rates of bacteria are about equal in coastal waters (Fuhrman \& Noble 1995), but in anoxic environments viruses may have a larger impact (Weinbauer \& Höfle 1998a). The potential for substantial impacts of viruses on community structure is high because viruses are host specific (Hennes et al. 1995). However, there is little direct evidence of the impact of viral lysis on bacterial community structure because it is difficult to separate the effects of viruses and grazers (Šimek et al. 2001).

The relative importance of mortality and growth regulation of bacterial community structure has implications for the impact of bacterial diversity on DOM consumption. The hypothesis that growth controls community structure in the Delaware estuary was not supported by analysis of thymidine and leucine-active bacteria, except perhaps for $\beta$-proteobacteria. In contrast, mortality appears to have left its mark on the size distribution of the bacteria. The relative importance of bottom-up (e.g. DOM supply) and top-down controls affects the impact of community structure on biogeochemical processes. When top down controls prevail community structure may play a large role in determining the processing of DOM. The impact of community composition on DOM consumption would be minimal if the composition of the community were dictated solely by substrate supply and concentrations; DOM would determine community structure, not vice versa. In contrast, community structure controlled by topdown influences could have a marked impact on the consumption of organic matter, since bacterial groups differ in the consumption of various types of DOM compounds (Cottrell \& Kirchman 2000), and no bacterial species is capable of consuming all organic compounds at high rates (Martinez et al. 1996). Therefore, when grazers and viruses determine community structure they may dictate the potential for organic matter consumption.
Acknowledgements. This research was supported by the US Department of Energy Biotechnological InvestigationsOcean Margins Program (BIOMP) and the National Science Foundation (OCE-9908808).

\section{LITERATURE CITED}

Amann RI, Binder BJ, Olson RJ, Chisholm SW, Devereux R, Stahl DA (1990) Combination of 16S ribosomal-RNAtargeted oligonucleotide probes with flow-cytometry for analyzing mixed microbial populations. Appl Environ Microbiol 56:1919-1925

Beardsley C, Pernthaler J, Wosniok W, Amann R (2003) Are readily culturable bacteria in coastal North Sea waters suppressed by selective grazing mortality? Appl Environ Microbiol 69:2624-2630

Bouvier TC, del Giorgio PA (2002) Compositional changes in free-living bacterial communities along a salinity gradient in two temperate estuaries. Limnol Oceanogr 47:453-470

Bouvier T, del Giorgio PA (2003) Factors influencing the detection of bacterial cells using fluorescence in situ hybridization (FISH): a quantitative review of published reports. FEMS Microbiol Ecol 44:3-15

Carman KR (1993) Microautoradiographic detection of microbial activity. In: Kemp PF, Sherr BF, Sherr EB, Cole JJ (eds) Handbook of methods in aquatic microbial ecology. Lewis Publishers, Boca Raton, FL, p 397-404

Chin-Leo G, Kirchman DL (1990) Unbalanced growth in natural assemblages of marine bacterioplankton. Mar Ecol Prog Ser 63:1-8

Cotner JB, Ammerman JW, Peele ER, Bentzen E (1997) Phosphorus-limited bacterioplankton growth in the Sargasso Sea. Aquat Microb Ecol 13:141-149

Cottrell MT, Kirchman DL (2000) Natural assemblages of marine proteobacteria and members of the CytophagaFlavobacter cluster consuming low- and high- molecularweight dissolved organic matter. Appl Environ Microbiol 66:1692-1697

Cottrell MT, Kirchman DL (2003) Contribution of major bacterial groups to bacterial biomass production (thymidine and leucine incorporation) in the Delaware estuary. Limnol Oceanogr 48:168-178

Crump BC, Armbrust EV, Baross JA (1999) Phylogenetic analysis of particle-attached and free-living bacterial communities in the Columbia River, its estuary, and the adjacent coastal ocean. Appl Environ Microbiol 65:3192-3204

del Giorgio PA, Bouvier TC (2002) Linking the physiologic and phylogenetic successions in free-living bacterial communities along an estuarine salinity gradient. Limnol Oceanogr 47:471-486

Ducklow HW (2000) Bacterial production and biomass in the oceans. In: Kirchman DL (ed) Microbial ecology of the oceans. Wiley, New York, p 85-120

Eilers H, Pernthaler J, Amann R (2000a) Succession of pelagic marine bacteria during enrichment: a close look at cultivation-induced shifts. Appl Environ Microbiol 66: $4634-4640$

Eilers H, Pernthaler J, Glöckner FO, Amann R (2000b) Culturability and in situ abundance of pelagic bacteria from the North Sea. Appl Environ Microbiol 66:3044-3051

Fisher TR, Lee KY, Berndt H, Benitez JA, Norton MM (1998) Hydrology and chemistry of the Choptank River basin. Water Air Soil Pollut 105:387-397

Fuhrman JA, Noble RT (1995) Viruses and protists cause similar bacterial mortality in coastal seawater. Limnol Oceanogr 40:1236-1242 
Fuhrman JA, Suttle CA (1993) Viruses in marine planktonic systems. Oceanography 6:50-62

Glöckner FO, Fuchs BM, Amann R (1999) Bacterioplankton compositions of lakes and oceans: a first comparison based on fluorescence in situ hybridization. Appl Environ Microbiol 65:3721-3726

Gonzalez JM, Sherr EB, Sherr BF (1990) Size-selective grazing on bacteria by natural assemblages of estuarine flagellates and ciliates. Appl Environ Microbiol 56:583-589

Gonzalez JM, Kiene RP, Moran MA (1999) Transformation of sulfur compounds by an abundant lineage of marine bacteria in the alpha-subclass of the class proteobacteria. Appl Environ Microbiol 65:3810-3819

Granger J, Price NM (1999) The importance of siderophores in iron nutrition of heterotrophic marine bacteria. Limnol Oceanogr 44:541-555

Hahn MW, Höfle MG (1999) Flagellate predation on a bacterial model community: interplay of size-selective grazing, specific bacterial cell size, and bacterial community composition. Appl Environ Microbiol 65:4863-4872

Hahn MW, Höfle MG (2001) Grazing of protozoa and its effect on populations of aquatic bacteria. FEMS Microbiol Ecol 35:113-121

Harvey HR, Mannino A (2001) The chemical composition and cycling of particulate and macromolecular dissolved organic matter in temperate estuaries as revealed by molecular organic tracers. Org Geochem 32:527-542

Hennes KP, Suttle CA, Chan AM (1995) Fluorescently labeled virus probes show that natural virus populations can control the structure of marine microbial communities. Appl Environ Microbiol 61:3623-3627

Hoch MP, Kirchman DL (1993) Seasonal and interannual variability in bacterial production and biomass in a temperate estuary. Mar Ecol Prog Ser 98:283-295

Hopkinson CS, Buffam I, Hobbie J, Vallino J and 11 others (1998) Terrestrial inputs of organic matter to coastal ecosystems: an intercomparison of chemical characteristics and bioavailability. Biogeochemistry 43:211-234

Hutchins DA, Campbell BJ, Cottrell MT, Takeda S (2001) Response of marine bacterial community composition to iron additions in three iron-limited regimes. Limnol Oceanogr 46:1535-1545

Jürgens K, Güde H (1994) The potential importance of grazing-resistant bacteria in planktonic systems. Mar Ecol Prog Ser 112:169-188

Jürgens K, Arndt H, Rothhaupt KO (1994) Zooplanktonmediated changes of bacterial community structure. Microb Ecol 27:27-42

Karner M, Fuhrman JA (1997) Determination of active marine bacterioplankton: a comparison of universal 16S rRNA probes, autoradiography, and nucleoid staining. Appl Environ Microbiol 63:1208-1213

Kim G, Scudlark JR, Church TM (2000) Atmospheric wet deposition of trace elements to Chesapeake and Delaware bays. Atmos Environ 34:3437-3444

Kirchman DL (2002) The ecology of Cytophaga-Flavobacteria in aquatic environments. FEMS Microbiol Ecol 39:91-100

Kirchman DL, Meon B, Cottrell MT, Hutchins DA, Weeks D, Bruland KW (2000) Carbon versus iron limitation of bacterial growth in the California upwelling regime. Limnol Oceanogr 45:1681-1688

Kirchman DL, Yu LY, Cottrell MT (2003) Diversity and abundance of uncultured Cytophaga-like bacteria in the Delaware estuary. Appl Environ Microbiol 69:6587-6596

Malmstrom RR, Kiene RP, Kirchman DL (in press) Identification and enumeration of bacteria assimilating dimethylsulfoniopropionate (DMSP) in the North Atlantic and Gulf of
Mexico. Limnol Oceanogr

Manz W, Amann R, Ludwig W, Wagner M, Schleifer KH (1992) Phylogenetic oligodeoxynucleotide probes for the major subclasses of proteobacteria - problems and solutions. Syst Appl Microbiol 15:593-600

Manz W, Amann R, Ludwig W, Vancanneyt M, Schleifer KH (1996) Application of a suite of 16S rRNA-specific oligonucleotide probes designed to investigate bacteria of the phylum Cytophaga-Flavobacter-Bacteroides in the natural environment. Microbiology 142:1097-1106

Martinez J, Smith DC, Steward GF, Azam F (1996) Variability in ectohydrolytic enzyme activities of pelagic marine bacteria and its significance for substrate processing in the sea. Aquat Microb Ecol 10:223-230

Morita RY (1997) Bacteria in oligotrophic environments: starvation-survival lifestyle, Chapman \& Hall, New York

Murray AG, Jackson GA (1992) Viral dynamics - a model of the effects of size, shape, motion and abundance of singlecelled planktonic organisms and other particles. Mar Ecol Prog Ser 89:103-116

Paerl HW, Zehr JP (2000) Marine nitrogen fixation. In: Kirchman DL (ed) Microbial ecology of the oceans. Wiley, New York, p 387-426

Pernthaler J, Sattler B, Simek K, Schwarzenbacher A, Psenner R (1996) Top-down effects on the size-biomass distribution of a freshwater bacterioplankton community. Aquat Microb Ecol 10:255-263

Pernthaler J, Posch T, Simek K, Vrba J and 5 others (2001) Predator-specific enrichment of actinobacteria from a cosmopolitan freshwater clade in mixed continuous culture. Appl Environ Microbiol 67:2145-2155

Ruimy R, Breittmayer V, Boivin V, Christen R (1994) Assessment of the state of activity of individual bacterial cells by hybridization with a ribosomal-RNA-targeted fluorescently labeled oligonucleotide probe. FEMS Microbiol Ecol 15:207-213

Sherr BF, Sherr EB, McDaniel J (1992) Effect of protistan grazing on the frequency of dividing cells in bacterioplankton assemblages. Appl Environ Microbiol 58: 2381-2385

Sieracki ME, Viles CL, Webb KL (1989) Algorithm to estimate cell biovolume using image analyzed microscopy. Cytometry 10:551-557

Šimek K, Vrba J, Pernthaler J, Posch T, Hartman P, Nedoma J, Psenner R (1997) Morphological and compositional shifts in an experimental bacterial community influenced by protists with contrasting feeding modes. Appl Environ Microbiol 63:587-595

Šimek K, Pernthaler J, Weinbauer MG, Hornak K, Dolan JR, Nedoma J, Masin M, Amann R (2001) Changes in bacterial community composition and dynamics and viral mortality rates associated with enhanced flagellate grazing in a mesoeutrophic reservoir. Appl Environ Microbiol 67: 2723-2733

Strom SL (2000) Bacterivory: interactions between bacteria and their grazers. In: Kirchman DL (ed) Microbial ecology of the oceans. Wiley, New York, p 351-386

Tabor PS, Neihof RA (1984) Direct determination of activities for microorganisms of Chesapeake Bay populations. Appl Environ Microbiol 48:1012-1019

Tortell PD, Maldonado MT, Granger J, Price NM (1999) Marine bacteria and biogeochemical cycling of iron in the oceans. FEMS Microbiol Ecol 29:1-11

Ward BB (1996) Nitrification and denitrification: probing the nitrogen cycle in aquatic environments. Microb Ecol 32: 247-261

Ward BB (2000) Nitrification and the marine nitrogen cycle. 
In: Kirchman DL (ed) Microbial ecology of the oceans. Wiley, New York, p 426-454

Weinbauer MG, Höfle MG (1998a) Significance of viral lysis and flagellate grazing as factors controlling bacterioplankton production in a eutrophic lake. Appl Environ Microbiol 64:431-438

Weinbauer MG, Höfle MG (1998b) Size-specific mortality of lake bacterioplankton by natural virus communities. Aquat Microb Ecol 15:103-113

Wommack KE, Colwell RR (2000) Virioplankton: viruses in

Editorial responsibility: Jed Fuhrman,

Los Angeles, California, USA aquatic ecosystems. Microbiol Mol Biol Rev 64:69-114

Zarda B, Hahn D, Chatzinotas A, Schonhuber W, Neef A, Amann RI, Zeyer J (1997) Analysis of bacterial community structure in bulk soil by in situ hybridization. Arch Microbiol 168:185-192

Zubkov MV, Fuchs BM, Archer SD, Kiene RP, Amann R, Burkill PH (2001) Linking the composition of bacterioplankton to rapid turnover of dissolved dimethylsulphoniopropionate in an algal bloom in the North Sea. Environ Microbiol 3:304-311

Submitted: January 13, 2003; Accepted: October 2, 2003 Proofs received from author(s): January 19, 2004 